Ilona Piurenko,

Doctor of Economics, Associate Professor of the Subdepartment of Company Production and Innovative Activity Management, Mykolaiv National Agrarian University (Mykolaiv, Ukraine;

Irina Banyeva,

Doctor of Economics, Professor, Professor of the Subdepartment of Company Production and Innovative Activity Management, Mykolaiv National Agrarian University (Mykolaiv, Ukraine);

Oleksii Garkusha,

Doctor of Economics, Professor, Professor of the Subdepartment of Company Production and Innovative Activity Management, Mykolaiv National Agrarian University (Mykolaiv, Ukraine)

\title{
DYNAMICS FACTORS OF UKRAINIAN ECONOMY INNOVATIVE TRANSFORMATION: MAIN POINTS AND SPECIFICS OF INFLUENCE
}

Innovative economy development factors are researched in this article. It is stated that the main factors assisting in development of Ukrainian innovative economy are internal current expenditures on technical scientific developments, scientific services and applied researches, performed by scientific organizations on their own. It is scientifically proved that the following items should be attributed to the list of urgent measures of the state innovative policy: fighting corruption intensification, political stabilization, strengthening of the Ukrainian Antimonopoly Committee role and responsibility for violation of Ukrainian antimonopoly legislation, increasing the intellectual property protection level and copyright up to international standards, increasing targeted state financing of scientific institutions, which produce innovative developments, demanded by the real economy sector, state development and private pilot projects of high-tech industrial parks based on leading domestic scientific institutions of respective profile.

Keywords: innovations, expenditures on scientific developments, corruption, political instability, inflation, intellectual property, antimonopoly regulation, targeted financing.

DOI: $10.21272 / \mathrm{mmi} .2017 .4-24$

Problem statement .The most important precondition for a successful reform in Ukrainian economy, improving its international competitive position and maximizing the benefits of deepening its integration into the global space is the technical and technological basis modernization of social production on an innovative basis. The innovative transformations necessity is subordinated to the main purpose of economy functioning - raising the living standards in the country's population. About these factors, is mentioned in "Global Competitiveness Report 2016-2017": «Accelerating innovation will be crucial to maintain the current level of welfare, and Europe can expect a high return on focusing their resources on educating its talented citizens» [22, p. 11].

Analysis of Recent Publications. Innovative transformations and formation of knowledge economy - one of the most important research directions. Studying the innovation phenomenon and their impact on the social production dynamics reflected in the works of many foreign scientists. In particular, these are works of J.A. Schumpeter [21], G.O. Mensh [20], K. Schwab [22]. Among native scientists "innovation theme" is reflected in research M.A. Pavlovskyi [2], L.I. Fedulova [17], N.M. Kraus [1] and others.

Previously unsettled parts identification of the general problem. However, whereas large number of scientific works with innovative themes, significant aspects of the scientific problems studying is not fully understood .The majority native researchers focus on theoretical and methodological direction, carry out a comparative analysis in quantitative characteristics of innovation in the Ukrainian economy and the developed countries economies, offer a conceptual framework in the national economy transition to innovation framework and the appropriate strategies development. In this case, the applied aspect of the problem requires additional research attention. In particular, the practical filling needs tactical measures to neutralize the factors, which impede the innovative progress of the national economy, substantiation of specific managerial decisions on practical implementation of state innovation policy, etc. 
The object of the article is to carry out a quantitative analysis of the factors influencing on the innovation transformations dynamics in the Ukrainian economy, measures validation to neutralize their destructive action.

Summarizing the main research material. According to the innovative development index Ukraine shows a very unstable dynamics (greater quantitative values of the rank means fall in respective rating) (Fig. 1) in Global Competitiveness Index Rankings. It is still to early to consider relative improvement of the analyzed index during marketing years 2015/16-2016/17 to be stable, since smoothing of the analyzed dynamic row with least-squares method provides no satisfactory result - credibility of approximation of all possible trend lines is not enough $\left(R^{2}<0.5\right)$.

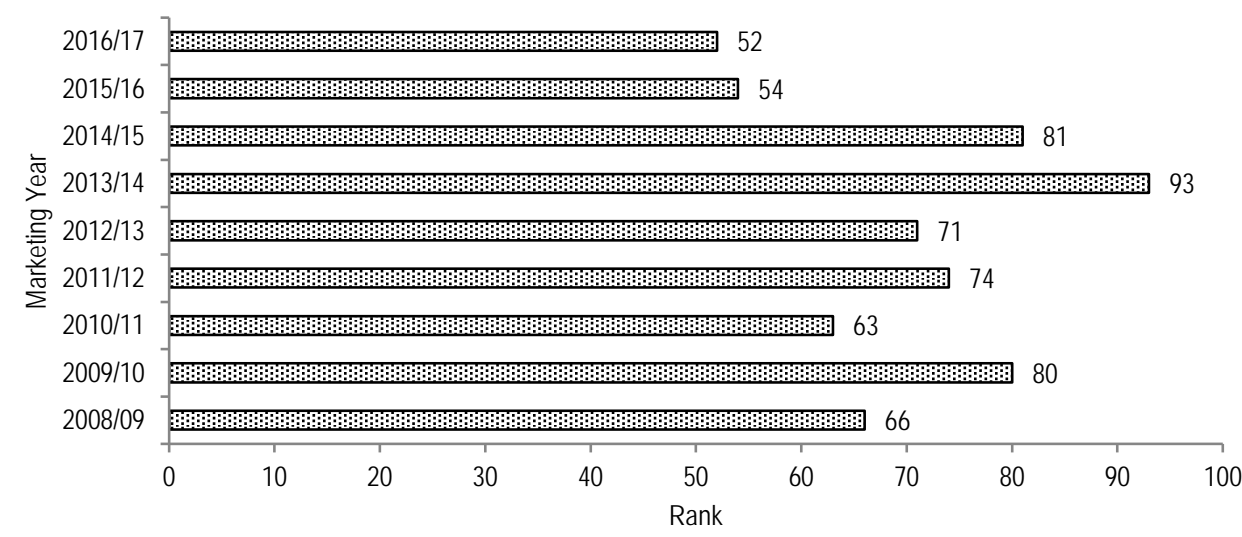

Figure 1 - Ukraine's place in the global competitiveness ranking in terms of innovation, rank (built by the authors based on [22-30])

This is confirmed with calculations based on national statistics data (Fig. 2).

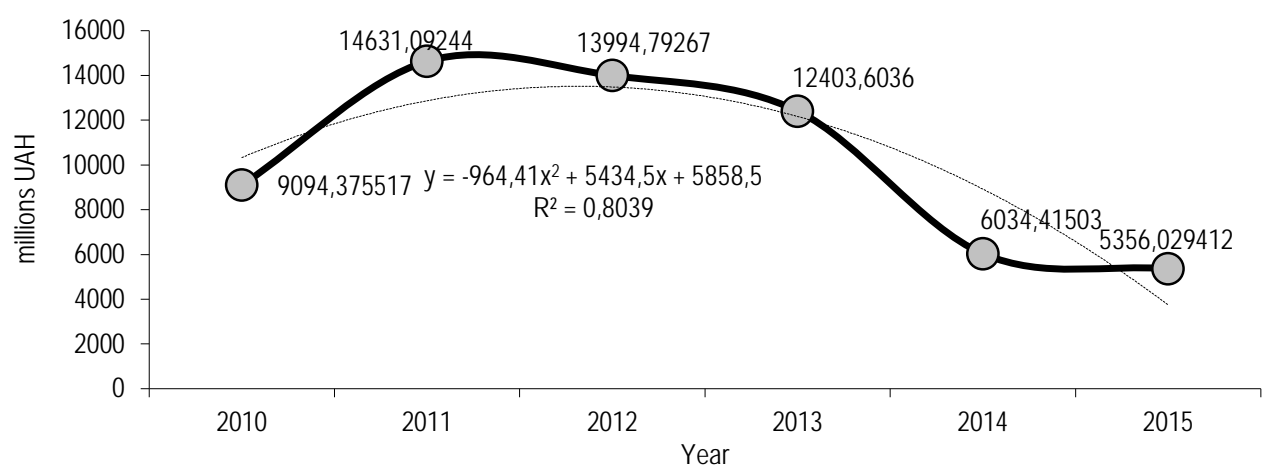

Figure 2 - The volume of realized Ukrainian innovative products for the market in real terms, $\mathrm{mln}$. (built by the author on the basis of [14])

As we see, rather stable negative tendency in the decrease of production and realization volumes of innovative products by Ukrainian companies still continues (Fig. 2).

Taking into account that innovative transformations leave no alternative, as key condition of successful reorganization in Ukrainian economy, it is necessary to detect and neutralize factors, which impede it, in 
time. This requires carrying out systematic monitoring of economic environment and including as many direct and indirect factors influence in analysis as possible.

An estimation methodology of quantitative and qualitative characteristics in the innovative economy development level includes may approaches. The following are singled out:

- science and Research Potential Index (WEF). Three factors are analysed: macroeconomic environment, state institutions and technologies;

- system of Innovative Activity Estimation Indicators of the Committee of European Community (CEC). It includes 16 indicators, divided into 4 groups: 1) human resources; 2) new knowledge generation; 3) knowledge transfer and application; 4) innovative activity financing;

- system of Innovative Activity Estimation in the Country using indicators according to European Innovation Scoreboard (EIS);

- innovation Union Scoreboard (IUS);

- knowledge Assessment Methodology of the World Bank (KAM). It includes a complex of 109 structural and qualitative indicators, united into four main groups: 1) The Economic Incentive and Institutional Regime; 2) Education and Human Resources; 3) The Innovation System; 4) Information and Communication Technology (ICT). As well, Knowledge Assessment Methodology offers determination of two consolidated index: The Knowledge Economy Index (KEI) and The Knowledge Index (KI);

- methodology of the Organization for Economic Cooperation and Development (OECD);

- unofficial approaches, offered and used by the economists and authors themselves in their researches in order to reveal the given tasks.

The following three methods are mainly used in Europe: evaluation method according to Organization for Economic Cooperation and Development (OECD); Data-base of Innovation Policy Measures; European Innovation Scoreboard (EIS) [18].

To determine the impact of individual factors on the dynamics of innovation in the Ukrainian economy, we decided to apply the comparative analysis method. For this, we used the Ukrainian regions statistics, based on regional differentiation in the sales volume of innovative products that are new to the market $(\mathrm{Y})$. When choosing the factors of influence, we proceeded from the methodological recommendations of the leading organizations and available data presented in the free access by the State Statistics Service of Ukraine (Table 1):

- $x_{1}$ - capital investments (UAH million). Innovations are always investments in the development, promotion and use (commercial or non-commercial) of new knowledge embodied in information, technology, technology, designs, products, etc.;

- $x_{2}-$ number of small and medium enterprises (per 10 thousand people of the existing population). Innovations are always associated with a serious commercial risk. Therefore, their promotion is impossible without the presence of a sufficient number of small and medium enterprises, which are the main recipients of venture capital;

- $x_{3}$ - internal current expenditures on scientific and technical developments, scientific services and applied researches performed by the own forces of scientific organizations (thousand UAH). Scientific organizations are the main source of new knowledge potentially suitable for commercial innovation;

- $\mathrm{X}_{4}$ - foreign trade turnover (in \% of gross regional product). As the "Global Competitiveness Report 2016-2017" says: "Open, the trade economy creates incentives for innovation and investment in new technologies, as firms are exposed to competition and new ideas, can benefit from the transfer of technology that comes with imports and foreign Investments" [22].

From such factors of influence as: "foreign direct investment (equity)", "the need of employers in workers to replace vacancies (vacant positions)", "The number of organizations that carry out scientific and technical work", "number of specialists who perform scientific and technical work" and the expansion factor for $\times 3$-element components had to be abandoned because they showed collinearity. 
Table 1 - Output information for the correlation-regression analysis according to the statistical data of regions of Ukraine for 2015 (built by authors based on [13])

\begin{tabular}{|c|c|c|c|c|c|}
\hline Region & 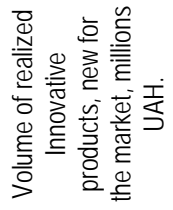 & 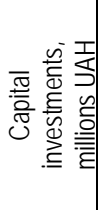 & 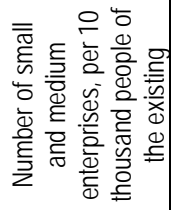 & 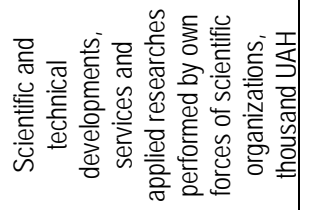 & 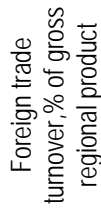 \\
\hline & $\mathrm{Y}$ & $\mathbf{X}_{1}$ & $x_{2}$ & $x_{3}$ & $\mathrm{X}_{4}$ \\
\hline Vinnitsa & 73.053 & 7373 & 59 & 19314.3 & 55.3 \\
\hline Volyn & 10.938 & 6167 & 54 & 13987.3 & 113.2 \\
\hline Dnipropetrovsk & 203.067 & 25920 & 84 & 1295760.6 & 119.1 \\
\hline Donetsk & 537.604 & 8304 & 27 & 163237.3 & 89.2 \\
\hline Zhytomyr & 88.632 & 4044 & 53 & 13379.4 & 50.4 \\
\hline Zakarpattya & 0 & 3778 & 49 & 28255.3 & 190.7 \\
\hline Zaporozhye & 682.270 & 7794 & 82 & 470729.1 & 133.0 \\
\hline Ivano-Frankivsk & 40.859 & 9609 & 57 & 34358.9 & 38.7 \\
\hline Kiev & 236.902 & 24359 & 105 & 158026.3 & 117.4 \\
\hline Kirovograd & 70.490 & 4057 & 79 & 53891.8 & 38.9 \\
\hline Lugansk & 360.890 & 2060 & 15 & 25891.9 & 40.1 \\
\hline Lviv & 416.791 & 13387 & 73 & 162401.9 & 79.5 \\
\hline Nikolaev & 11.036 & 5990 & 91 & 289069.1 & 134.4 \\
\hline Odesa & 199.610 & 9984 & 100 & 173680 & 78.6 \\
\hline Poltava & 0.269 & 8338 & 70 & 39388.9 & 71.8 \\
\hline Rivne & 17.959 & 4334 & 45 & 8243.2 & 44.2 \\
\hline Sumy & 1244.958 & 3663 & 52 & 111552.3 & 72.6 \\
\hline Ternopil & 74.877 & 3828 & 48 & 8366.1 & 55.5 \\
\hline Kharkiv & 2155.969 & 11247 & 92 & 1628420.3 & 59.3 \\
\hline Kherson & 10.073 & 3107 & 75 & 20703.3 & 35.6 \\
\hline Khmelnitsky & 2.091 & 6809 & 54 & 13131.4 & 44.9 \\
\hline Cherkassy & 39.777 & 4486 & 67 & 76535 & 37.6 \\
\hline Chernivtsi & 0 & 2789 & 45 & 33248.3 & 27.1 \\
\hline Chernihiv & 38.945 & 3550 & 57 & 42849.3 & 72.3 \\
\hline
\end{tabular}

Results of Correlation and Regression Analysis:

1) Correlation coefficient: $R=0.739$; thus, relation is close $(R>0.7)$;

2) Coefficient of determination: $R^{2}=0.546$; thus, function variability is $54.6 \%$ determined by the variability of the selected factors;

3) Fisher's test: $F_{a}=5.729, F_{c}=2.895, F_{a}>F_{c}$; thus, there is a relation between the function and the factors;

4) Student's test: $t_{a}=7.111, t_{c}=2.093, t_{a}>t_{c}$, thus, regression coefficient is statically significant;

5) Regression equation: $Y=336.842-0.024 x_{1}-0.844 x_{2}+0.001 x_{3}-0.587 x_{4}$.

Correlation matrix contains no pair correlation coefficients rxixj higher than 0.7 , which shows the absence of correlated regressors, so the model is not multicollinear (Tab. 2).

Table 2 - Correlation Matrix (author's own calculations)

\begin{tabular}{|l|l|l|l|l|l|}
\hline & \multicolumn{1}{|c|}{$\mathrm{Y}$} & \multicolumn{1}{|c|}{$\mathrm{X}_{1}$} & \multicolumn{1}{|c|}{$\mathrm{X}_{2}$} & \multicolumn{1}{c|}{$\mathrm{X}_{3}$} & $\mathrm{X}_{4}$ \\
\hline $\mathrm{Y}$ & 1 & & & & \\
\hline $\mathrm{X}_{1}$ & 0.145602577 & 1 & & & \\
\hline $\mathrm{X}_{2}$ & 0.173221552 & 0.574778473 & 1 & & \\
\hline $\mathrm{X}_{3}$ & 0.683904186 & 0.549277251 & 0.451286101 & 1 & \\
\hline $\mathrm{X}_{4}$ & 0.019234288 & 0.34959286 & 0.27664433 & 0.207603119 & 1 \\
\hline
\end{tabular}


Correlation and Regression Analysis provided rather unexpected results, which need economic interpretation and form extremely important conclusions.

As it is seen from the regression equation, factors $x_{1}, x_{2}$ and $x_{4}$ have inverse influence on the function. In other words, the volumes of realization of innovative products, which are new for the market, decrease in case of increase of the amount of capital investments, small and medium-sized companies and foreign trade turnover. Taking into account the amount of pair correlation coefficients between the function and given factors: $r_{Y \times 1}=0.146 ; r_{Y \times 2}=0.173 ; r_{Y \times 4}=0.019$ (Tab. 2), we may state that connection is rather not inversed, but generally absent. Detailed analysis of the reasons of the found phenomenon allowed us to determine the following:

1) research of the capital investments structure has shown that in 2016 such potentially innovative areas of investment as Information and Telecommunications, Professional, Scientific and Technical Activities and Education took only $4.7 \%, 1.1 \%$ and $0.3 \%$ respectively. We may conclude then, that the national capital investments are not innovation-oriented. In our opinion the main reason for that are excessive risks of carrying out commercial activity in Ukraine. Investments in innovations themselves are risky even in highly developed countries. If we add specific domestic business risks, then potential benefits from innovations implementation compensate no possible losses in case of risky situation occurrence. On the other hand, as a result of reinsurance, their price shall be so high that potentially successful innovative product shall find no ready sale. The main destructive factors of business activity performance include corruption, political instability and inflation (Fig. 3). Their share takes $39.1 \%$ of influence.

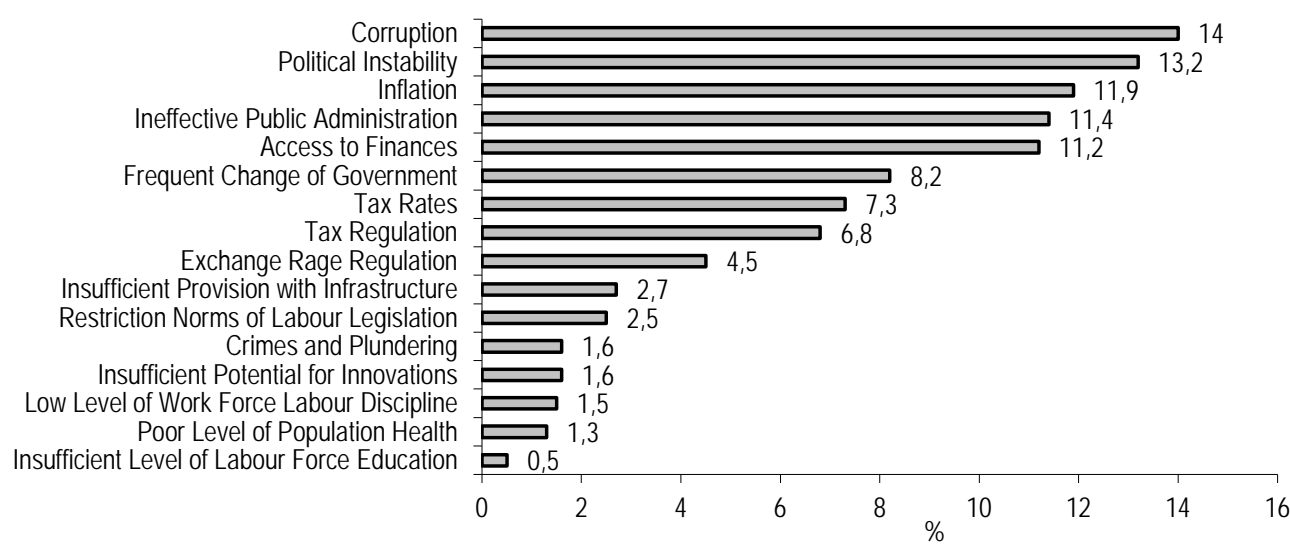

\section{Figure 3 - Factors that impede conducting business in Ukraine according to the Global Competitiveness Report in 2016-2017 (built by authors based on [30])}

2) developed small and medium-sized business is a necessary, but insufficient condition for innovative development of economy. Indeed, small and medium-sized companies are the main recipients of investments in venture capital. However, if donors of such capital are large companies, not interested in investments into innovations, these do not occur. Besides, the influence of negative factors, which impede conduct of business (Fig. 3), does not stimulate any small and middle-sized companies to invest into risky projects with long-term payback period, but orients them for business activity with much shorter production cycle.

3) the same concerns the open economy, which is not an automatic guarantee of import of new knowledge and progressive technologies. E.g., despite the growth of Ukrainian open economy, the volume of import of potentially innovative services had reduced during last 3 years (Tab. 3). In our opinion, the following are the main reasons of the low level of advanced technology transfer to Ukraine: 
- insufficient level of intellectual property protection: according to the data of the annual report of the International Intellectual Property Alliance (IIPA) in 2016 Ukraine took the first place in rating of the countries, which violate the intellectual property rights the most frequently [16];

- more than a half of the national market still has a noncompetitive structure. According to the data of the Antimonopoly Committee of Ukraine in 2015 only $42.7 \%$ of general volume of products were sold in markets with competitive structure; $16.7 \%$ - in markets with signs of collective dominance or oligopol markets (where the share of the three largest business subjects exceeded $50 \%$ ); $30.8 \%$ of general volume of products realization fell to markets with signs of sole dominance (where the share of the largest business subject amounted to more than $35 \%$ ); $9.8 \%$ of the general volume of goods, works and services were realized on monopolized markets (where the share of the largest business subject amounted to more than $90 \%$ ). Analysis of tendencies of competitiveness structural preconditions changes since 2001 evidences that from the beginning of 2008 World Economic Crisis a tendency of the competitiveness level decrease has taken place in Ukrainian economy. At the same time, if within 2010-2011 the reduction of the level of competitive markets occurred at the cost of oligopol markets expansion, where competitiveness is possible under certain conditions, the gradual increase of the markets shares with signs of individual dominance or monopolized markets, where competitiveness is practically out of the question, has taken place since 2012 [3].

Table 3 - Imports into Ukraine of potentially innovative services, mIn USA (built by authors based on [15])

\begin{tabular}{|l|c|c|c|c|}
\hline Service Type & 2013 & 2014 & 2015 & 2016 \\
\hline Total, & 2026.8 & 1392.7 & 1144.5 & 1101.3 \\
\hline including: & & & & \\
\hline Royalties and other services related to the use of intellectual property & 854.2 & 450.5 & 301.6 & 323.1 \\
\hline $\begin{array}{l}\text { Services in the field of telecommunications, computer and information } \\
\text { services }\end{array}$ & 698.4 & 512.0 & 548.4 & 420.4 \\
\hline Research and development services & 42.4 & 23.3 & 14.3 & 24.4 \\
\hline Scientific and technical services & 221.6 & 140.9 & 127.2 & 69.9 \\
\hline Services on processing and elimination of environmental pollution & 132.7 & 93.7 & 83.8 & 167.3 \\
\hline Operating lease services & 77.5 & 172.3 & 69.2 & 96.2 \\
\hline
\end{tabular}

The monopoly high price $\left(C_{m}\right)$ makes it possible to obtain a monopoly high profit $\left(p_{1}\right)$, which, in other equal conditions, in the presence of competition, is zero:

$$
C_{m}=c+v+p+p_{1}
$$

where $C_{m}$ - monopoly high price; $c$ - fixed capital; $v$ - variable capital; $p$ - average profit; $p_{1}$ - a monopoly high profit.

The essential difference between domestic and foreign markets prices means that producers or trading companies have a monopoly opportunity individually or in agreement influence the pricing in the domestic market.

The negative consequences of monopoly rule in the Ukrainian economy are the unfair prices establishment (monopoly overestimated) and the lack of incentives for modernization. A striking example of this problem is the economic activity result in the domestic automobile monopoly "Ukravto." Thus, journalists from the Carreviewauto portal have published a comparative cost table of new cars in Ukraine and Russia as the prices for the end of January-beginning of February 2016 - ZAZ Lanos, which is produced in Zaporozhye, in the domestic market cost $9600 \$$, about., While the Russian buyer he was available for $5182 \$$.

The average difference in price for models that participated in comparison was over $68 \%$ [19]. The losses caused by the monopolist to the Ukrainian consumers are not only in overpriced prices, but also 
because they are forced to buy legally obsolete cars. After all, the preferential (uncompetitive) regime, which has been around for 25 years now due to the high collection of cars, did not stimulate the automobile monopolist to develop and serially produce their own competitive automobile model.

Therefore, according to our research, one of the several factors that stimulate the innovative economy development in Ukraine is the internal operating costs, research and development, scientific services and applied research performed by their own scientific organizations. Taking into account criticality of the factor, we should mention, that resource potential of domestic scientific organizations, which are able to produce competitive knowledge, is not endless. Moreover, we are referring not only to financial resources. Topical national problems are formation and accumulation of human capital.

Table 4 - Admission of Students to the Institutes of Higher Educations of Ukraine of the $3^{\text {rd }}=4^{\text {th }}$ accreditation level, for Initial Study Cycle (1 ${ }^{\text {st }}$ Year), in persons [4-9]

\begin{tabular}{|l|c|c|c|c|c|c|}
\hline Training direction & 2010 & 2011 & 2012 & 2013 & 2014 & 2015 \\
\hline Natural Sciences & 11395 & 8826 & 9815 & 9760 & 8460 & 7360 \\
\hline Physical and Mathematical Sciences & 4663 & 3131 & 3908 & 3895 & 3368 & 2005 \\
\hline Systematic Sciences and Cybernetics & 2735 & 2124 & 2847 & 3041 & 2588 & 2480 \\
\hline
\end{tabular}

During recent years (Tab. 4) we observe a stable tendency to reduce the amount of persons interested in admission to Institutions of Higher Education of the $3^{\text {rd }}-4^{\text {th }}$ accreditation level for the $1^{\text {st }}$ year of study specializing in natural, physical and mathematical, systematic sciences and cybernetics - sciences, which form a basis for knowledge economy. As a result, the number of scientists in these specialities reduces (Tab. 5).

Table 5 - Admitted to Post-Graduate Courses in Ukraine, persons [10-12]

\begin{tabular}{|l|c|c|c|c|c|c|}
\hline A branch of Science & 2010 & 2011 & 2012 & 2013 & 2014 & 2015 \\
\hline Physics and Mathematical & 678 & 644 & 632 & 585 & 525 & 419 \\
\hline Chemical & 156 & 139 & 154 & 140 & 110 & 116 \\
\hline Biological & 417 & 416 & 414 & 370 & 326 & 313 \\
\hline Technical & 2170 & 2174 & 2056 & 1874 & 1573 & 1426 \\
\hline
\end{tabular}

We should name the following reasons in the first place among the reasons, causing the given consequences:

1) Threatening low level of school-leavers' basic knowledge in mathematics, physics, chemistry and computer science. E.g., 25.3 thousand participants of the external independent evaluation, or $24 \%$ of all registered ones, did not pass test in mathematics in 2015 . This is caused, first of all, by the catastrophically low level of professional training in elementary, middle and high school teachers, especially in countryside. Today the teacher career is not popular due to unjustified low salary. As a result, young people often go into educationalists not by vocation, but those, who are unable to compete for relatively highly paid jobs by force of subjective reasons in other economy sectors. Non-transparency of many domestic institutions in higher education functioning allows them to buy their diplomas not only in a literal, but in a figurative sense also;

2) The reduction of scientists in physical, mathematical, natural and technical sciences is a decrease direct consequence in the number of admissions to higher educational institutions in the related training area. Equally important is the funding of domestic scholars. We are talking not only about low wages, but also about the critical shortage of funds needed to equip and operate modern laboratories, conduct experiments and field research, purchase consumables, travel abroad for conferences, internships, publication of research results, etc. 
In addition to purely internal risks, the loss threat of "brain" comes from the outside. Thus, the report of the Global Competitiveness 2016-2017 (The Global Competitiveness Report 2016-2017) stating that the EU one of the most critical aspects in the innovation factor in the competitiveness human capital formation problems. In the analysis of seven important human capital indicators (the quality of education in mathematical and natural sciences, the quality of the education system, Internet access in schools, the local availability of specialized training services, the ability of the country to retain talent, the presence of scientists and engineers), draws attention to the fact that the group education indicators most problems occur on education of mathematics and natural sciences. Europe feels a lack of gifted youth with respective knowledge. At present, there is a low index of attraction and keeping of gifted people in EU from people outside the Community [22]. This creates some threats for development of dynamic European knowledge economy, which is forced to compete with the analogical systems of the other countries of the world - US first of all. Such authoritative remarks are an immediate call for action for public administrations of highly developed EU countries. There are no doubts, that the nearest European neighbours such as Ukraine, Moldova, Belarus, Georgia and Russian Federation come to EU focus first of all. Absorbing ability of state and private scientific institutes of EU also alarms us - they are able to absorb the most part of domestic mathematical and other talents without some problems. We should not forget that beside EU, the USA is even much more successful "hunter" of foreign "brains".

In the context of the given problem, Ukrainian authorities, large industrial and agrarian companies face a very complicated task of not only directing enough organizational efforts and financial recourses to increase the supply of competitive knowledge, but forming demand on it inside the country. Probably, one of the ways to solve this task is to create the national analogue of the Silicon Valley.

\section{Conclusions:}

1) studying the effect of capital investments size $\left(x_{1}\right)$, the number of small and middle-sized business $\left(x_{2}\right)$, the internal current expenses on scientific and technical developments, scientific services and applied researches, performed by the scientific organizations on their own $\left(x_{3}\right)$, foreign trade turnover $\left(x_{4}\right)$, on the volume of sales innovative products that are new to the market $(Y)$, revealed the following:

- the relation between $Y$ and $x_{1}$ is absent. This means that the domestic capital investment is not innovation-oriented. The main reason of it is the excessive risks of economic activities in Ukraine. Three main destructive business factors are: corruption, political instability and inflation;

- the relation between $Y$ and $x_{2}$ is absent. This means that developed small and medium entrepreneurship is necessary, but insufficient condition for innovation economy development. Small and medium-sized enterprises are the main recipients of investment in venture capital. However, if donors of such capital are large enterprises that are not interested in investing to innovation, then they do not happen. The influence of negative factors - corruption, political instability and inflation, does not stimulate any small and middle-sized companies to invest into risky projects with long-term payback period, but orients them for business activity with much shorter production cycle;

- the connection between $Y$ and $x 4$ is absent. This means that growth of economy openness is not an automatic guarantee of the new knowledge import and advanced technologies. For the period of 20132016 years, the imports volume of potentially innovative services declined despite the growth of Ukrainian economy. The main reasons of the low advanced technology transfer level in Ukraine are insufficient level of intellectual property protection and non-competitive structure of the national market;

- the connection between $Y$ and $x_{3}$ is high. This means that one of the many factors that stimulate the development of an innovative economy is the internal running costs of scientific and technical development, scientific services and applied research carried out by the own forces of scientific organizations;

2) the list of urgent measures in state innovation policy can include:

- strengthening the fighting corruption; 
- political stabilization. The most effective instruments for its achievement are to build an trust atmosphere between citizens and public authorities, an information campaign aimed at destroying political populism, comprehensive measures of patriotic education;

- strengthening the role of the Ukrainian Antimonopoly Committee and responsibility for violation of Ukrainian anti-monopoly legislation;

- raising the protection level of intellectual property and copyright to international standards;

- an increase in the targeted state financing of scientific organizations that produce innovative developments that are in demand from the side of the economy real sector;

- development of state and private pilot projects of high-tech industrial parks based on leading domestic scientific institutions of respective profile.

Perspectives of further developments: an upcoming trend for further research is the pilot projects development in the form of technology parks and innovative business incubators.

1. Краус Н.М. Інституціональний дизайн мезорівня інноваційної економіки: фрактально-фасеточна модель / Н.М. Краус // Економічний часопис-XXI. - 2015. - № 3-4(1). - С. 4-7.

2. Павловський М.А. Макроекономіка перехідного періоду: Український контекст / М.А. Павловський. - Київ : Техніка, 1999. $-366 \mathrm{c}$

3. Розпорядження № 3-рп від 14.03.2016 «Звіт Антимонопольного комітету України за 2015 рік» [Електронний ресурс]/ Антимонопольний комітет України. - 135 c. - Режим доступу: http://www.amc.gov.ua/amku/doccatalog /doc ument?id=122547.

4. Статистичний бюлетень "Основні показники діяльності вищих навчальних закладів України на початок 2010/11 навчального року» / відп. за вип. І.В. Калачова. - Київ : Державний комітет статистики України, 2011. - 207 с.

5. Статистичний бюлетень «Основні показники діяльності вищих навчальних закладів України на початок 2011/12 навчального року» / відп. за вип. І.В. Калачова. - К.: Державна служба статистики України, 2012. - 219 с.

6. Статистичний бюлетень «Основні показники діяльності вищих навчальних закладів України на початок 2012/13 навчального року» / відп. за вип. І.В. Калачова. - Київ : Державна служба статистики України, 2013. - 188 с.

7. Статистичний бюлетень «Основні показники діяльності вищих навчальних закладів України на початок 2013/14 навчального року» / відп. за вип. І.В. Калачова. - Київ : Державна служба статистики України, 2014. - 165 с.

8. Статистичний бюлетень «Основні показники діяльності вищих навчальних закладів України на початок 2014/15 навчального року» / відп. за вип. О.О. Кармазіна. - Київ : Державна служба статистики України, 2015. - 169 с.

9. Статистичний бюлетень «Основні показники діяльності вищих навчальних закладів України на початок 2015/16 навчального року» / відп. за вип. О. О. Кармазіна. - Київ : Державна служба статистики України, 2016. - 171 с.

10. Наукова та інноваційна діяльність в Україні за 2012 рік: статистичний збірник. - Київ : Державна служба статистики України, 2013. - 287 с.

11. Наукова та інноваційна діяльність в Україні за 2014 рік: статистичний збірник. - Київ : Державна служба статистики України, 2015. - 255 с.

12. Наукова та інноваційна діяльність в Україні за 2015 рік: статистичний збірник. - Київ : Державна служба статистики України, 2016. - 257 с

13. Регіони України за 2016 рік: статистичний збірник. - Київ : Державна служба статистики України, 2016. - 299 с.

14. Статистичний щорічник України за 2015 рік: статистичний збірник. - Київ : Державна служба статистики України, 2016. $-575 \mathrm{c}$.

15. Структура експорту-імпорту за видами послуг [Електронний ресурс]. - Режим доступу: http://www.ukrstat.gov.ua/operativ/ operativ2016/ zd/ str eip kv/ str_eip kv u/str_eip2016 u.htm.

16. Україну визнано найбільшим у світі «піратським оффшором» [Електронний ресурс] // РБК-Україна. - Режим доступу: https:// www.rbc.ua/ukr/news/ukraina-priznana-naibolee-piratskoy-stranoy-1455620214.html.

17. Федулова Л.І. Інноваційність економіки ЄС та України: напрями скорочення розриву / Л.І. Федулова // Економічний часопис-XXI. - 2016. - № 156(1-2). - С. 22-25.

18. Ивлес А. Структурные изменения в государстве как результат инвестирования в инновационный сектор / А. Ивлес // Економічний часопис-XXI. - 2014. - №7-8(2). - С. 16-19.

19. Отечественный 3 A3 Lanos в Украине продается вдвое дороже, чем в России [Електронний ресурс]. - Режим доступу: http://uww.segodnya.ua/economics/avto/otechestvennyy-zaz-lanos-v-ukraine-prodaetsya-vdvoe-dorozhe-chem-v-rossii-smi-691862.html.

20. Mensh G. Stalemate in technology: innovation overcome the depression / G. Mensh. - Cambridge: Mass, 1979. - $241 \mathrm{p}$

21. Schumpeter J.A. Capitalism, Socialism and Democracy / J.A. Schumpeter. - New York, London: Harper \& Row, 1942. - 381 p.

22. The Global Competitiveness Report 2008-2009. - Geneva: World Economic Forum, 2008. - $513 p$.

23. The Global Competitiveness Report 2009-2010. - Geneva: World Economic Forum, 2009. - $492 p$

24. The Global Competitiveness Report 2010-2011. - Geneva: World Economic Forum, 2010. - 516 p. 
25. The Global Competitiveness Report 2011-2012. - Geneva: World Economic Forum, 2011. - $544 p$.

26. The Global Competitiveness Report 2012-2013. - Geneva: World Economic Forum, 2012. - $545 p$.

27. The Global Competitiveness Report 2013-2014. - Geneva: World Economic Forum, 2013. - $569 p$.

28. The Global Competitiveness Report 2014-2015. - Geneva: World Economic Forum, 2014. - $565 \mathrm{p}$.

29. The Global Competitiveness Report 2015-2016. - Geneva: World Economic Forum, 2015. - $403 p$.

30. The Global Competitiveness Report 2016-2017. - Geneva: World Economic Forum, 2016. - 400 p

1. Kraus, N.M. (2015). Instytutsionalnyy dyzayn mezorivnya innovatsiynoyi ekonomiky: fraktalno-fasetochna model [lnstitutional design on meso-level of innovative economy: fractal-facet model]. Ekonomicnij Casopis-XXI - Economic Annals-XXI, 3-4(1), 4-7 [in Ukrainian].

2. Pavlovskyy, M.A. (1999). Makroekonomika perekhidnoho periodu: Ukrayinskyy kontekst [Macroeconomics in transition: Ukrainian context]. Kiev: Tekhnika [in Ukrainian].

3. Antymonopolnyy komitet Ukrayiny (2016). Rozporyadzhennya No 3-rp vid 14.03.2016 "Zvit Antymonopolnoho komitetu Ukrayiny za 2015 rik" [The report of the Antimonopoly Committee of Ukraine for 2015 (Order)]. amc.gov.ua. Retrieved from: http://www.amc.gov.ua/amku/doccatalog/document?id=122547 [in Ukrainian].

4. Kalachova, I. V. (Eds.) (2011). Statystychnyi biuleten «Osnovni pokaznyky diialnosti vyshchykh navchalnykh zakladiv Ukrainy na pochatok 2010/11 navchalnoho roku» [Statistical Bulletin "The main indicators of the activity of higher educational institutions of Ukraine at the beginning of the 2010/11 school year"]. Kyiv: Derzhavnyi komitet statystyky Ukrainy [in Ukrainian].

5. Kalachova, I. V. (Eds.) (2012). Statystychnyi biuleten «Osnovni pokaznyky diialnosti vyshchykh navchalnykh zakladiv Ukrainy na pochatok 2011/12 navchalnoho roku» [Statistical Bulletin "The main indicators of the activity of higher educational institutions of Ukraine at the beginning of the 2011/12 school year"]. Kyiv: Derzhavnyi komitet statystyky Ukrainy [in Ukrainian].

6. Kalachova, I. V. (Eds.) (2013). Statystychnyi biuleten «Osnovni pokaznyky diialnosti vyshchykh navchalnykh zakladiv Ukrainy na pochatok 2012/13 navchalnoho roku» [Statistical Bulletin "The main indicators of the activity of higher educational institutions of Ukraine at the beginning of the 2012/13 school year"]. Kyiv: Derzhavnyi komitet statystyky Ukrainy [in Ukrainian].

7. Kalachova, I. V. (Eds.) (2014). Statystychnyi biuleten «Osnovni pokaznyky diialnosti vyshchykh navchalnykh zakladiv Ukrainy na pochatok 2013/14 navchalnoho roku» [Statistical Bulletin "The main indicators of the activity of higher educational institutions of Ukraine at the beginning of the 2013/14 school year"]. Kyiv: Derzhavnyi komitet statystyky Ukrainy [in Ukrainian].

8. Kalachova, I. V. (Eds.) (2015). Statystychnyi biuleten «Osnovni pokaznyky diialnosti vyshchykh navchalnykh zakladiv Ukrainy na pochatok 2014/15 navchalnoho roku» [Statistical Bulletin "The main indicators of the activity of higher educational institutions of Ukraine at the beginning of the 2014/15 school year"]. Kyiv: Derzhavnyi komitet statystyky Ukrainy [in Ukrainian].

9. Kalachova, I. V. (Eds.) (2016). Statystychnyi biuleten «Osnovni pokaznyky diialnosti vyshchykh navchalnykh zakladiv Ukrainy na pochatok 2015/16 navchalnoho roku» [Statistical Bulletin "The main indicators of the activity of higher educational institutions of Ukraine at the beginning of the 2015/16 school year"]. Kyiv: Derzhavnyi komitet statystyky Ukrainy [in Ukrainian].

10. Naukova ta innovatsiyna diyalnist v Ukrayini za 2012 rik: statystychnyy zbirnyk [Ukraine's research and innovation in 2012: Statistical Yearbook] (2013). Kyiv: Derzhavna sluzhba statystyky Ukrayiny [in Ukrainian].

11. Naukova ta innovatsiyna diyalnist v Ukrayini za 2014 rik: statystychnyy zbirnyk [Ukraine's research and innovation in 2014: Statistical Yearbook] (2015). Kyiv: Derzhavna sluzhba statystyky Ukrayiny [in Ukrainian].

12. Naukova ta innovatsiyna diyalnist v Ukrayini za 2015 rik: statystychnyy zbirnyk [Ukraine's research and innovation in 2015 : Statistical Yearbook] (2016). Kyiv: Derzhavna sluzhba statystyky Ukrayiny [in Ukrainian].

13. Rehiony Ukrayiny za 2016 rik: statystychnyy zbirnyk [Regions of Ukraine in 2016: Statistical Yearbook] (2017). Kyiv: Derzhavna sluzhba statystyky Ukrayiny [in Ukrainian].

14. Statystychnyy shchorichnyk Ukrayiny za 2015 rik: statystychnyy zbirnyk [Statistical Yearbook of Ukraine in 2015: Statistical Yearbook] (2016). Kyiv: Derzhavna sluzhba statystyky Ukrayiny [in Ukrainian].

15. Struktura eksportu-importu za vydamy posluh [Structure of export-import of services (by guarter)] (n.d.). ukrstat.gov.ua. Retrieved from: http://www.ukrstat.gov.ua/operativ/operativ2016/zd/str_eip_kv/str_eip_kv_u/str_eip2016_u.htm [in Ukrainian].

16. Ukrayinu wyznano naybilshym u sviti «piratskym ofshorom» [Ukraine recognized as a largest world's «offshore pirate»] (n.d.). rbc.ua. Retrieved from: https://www.rbc.ua/ukr/news/ukraina-priznana-naibolee-piratskoy-stranoy-1455620214.html [in Ukrainian].

17. Fedulova, L.I. (2016). Innovatsiynist ekonomiky YES ta Ukrayiny: napryamy skorochennya rozryvu [Innovativeness of the economies of the EU and Ukraine: undertakings to narrow the gap]. Ekonomicnij Casopis-XXI - Economic Annals-XXI, 156(1-2), 22-25. [in Ukrainian]

18. Ivlevs, A. (2014). Strukturnie izmeneniya v gosudarstve kak rezultat investirovaniya v innovatsionniy sektor [State structures changes as a result of investing in innovation sector]. Ekonomicnij Casopis-XXI - Economic Annals-XXI, 7-8(2), 16-19 [in Russian].

19. Otechestvenniy ZAZ Lanos v Ukraine prodaetsya vdvoe dorozhe, chem v Rossii - SMI [Domestic ZAZ Lanos in Ukraine sold twice as expensive as in Russia - media] (2016). segodnya.ua. Retrieved from: http://www.segodnya.ua/economics/avto/otechestvennyy-zazlanos-v-ukraine-prodaetsya-vdvoe-dorozhe-chem-v-rossii-smi-691862.html [in Russian].

20. Mensh, G. (1979). Stalemate in technology: innovation overcome the depression. Cambridge: Mass.

21. Schumpeter, J. A. (1942). Capitalism, socialism and democracy. New York, London: Harper.

22. The Global Competitiveness Report 2008-2009 (2008). Geneva: World Economic Forum.

23. The Global Competitiveness Report 2009-2010 (2009). Geneva: World Economic Forum.

24. The Global Competitiveness Report 2010-2011 (2010). Geneva: World Economic Forum. 
25. The Global Competitiveness Report 2011-2012 (2011). Geneva: World Economic Forum.

26. The Global Competitiveness Report 2012-2013 (2012). Geneva: World Economic Forum.

27. The Global Competitiveness Report 2013-2014 (2013). Geneva: World Economic Forum.

28. The Global Competitiveness Report 2014-2015 (2014). Geneva: World Economic Forum.

29. The Global Competitiveness Report 2015-2016 (2015). Geneva: World Economic Forum.

30. The Global Competitiveness Report 2016-2017 (2016). Geneva: World Economic Forum.

I.0. Піюренко, д-р екон. наук, доцент кафедри управління виробництвом та інноваційною діяльністю підприємств, Миколаївський національний аграрний університет (м. Миколаїв, Україна);

I.O. Банєва, д-р екон. наук, професор, професор кафедри управління виробництвом та інноваційною діяльністю підприємств, Миколаївський національний аграрний університет (м. Миколаїв, Україна);

О.М. Гаркуша, д-р екон. наук, професор, професор кафедри управління виробництвом та інноваційною діяльністю підприємств, Миколаївський національний аграрний університет (м. Миколаїв, Україна)

Фактори динаміки інноваційних перетворень української економіки: суть та особливості впливу

В статті досліджуються фактори динаміки розвитку інноваційної економіки. Стверджується, що головним фактором, який сприяє розвитку інноваційної економіки України є внутрішні поточні витрати на науково-технічні розробки, наукові послуги та прикладні дослідження виконані власними силами наукових організацій. Доводиться, що до переліку невідкладних заходів державної інноваційної політики слід віднести посилення боротьби з корупиією, політичну стабілізацію, посилення ролі Антимонопольного комітету України та відповідальності за порушення антимонопольного законодавства України, підвищення рівня захисту інтелектуальної власності та авторського права до міжнародних стандартів, збільшення адресного державного фьнансування наукових організацій, які продукують інноваційні розробки, що користуються попитом збоку реального сектору економіки, розробка державно-приватних пілотних проектів високотехнологічних технопарків на базі провідних вітчизняних наукових установ відповідного профрілю.

Ключові слова: інновації, витрати на наукові розробки, корупція, політична нестабільність, інфляцція, інтелектуальна власність, антимонопольне регулювання, адресне фінансування.

И.А. Пиюренко, д-р экон. наук, доцент кафедры управления производством и инновационной деятельностью предприятий, Николаевский национальный аграрный университет (г. Николаев, Украина);

И.А.Банева, д-р экон. наук, професор, професор кафедры управления производством и инновационной деятельностью предприятий, Николаевский национальный аграрный университет (г. Николаев, Украина);

А.Н.Гаркуша, д-р экон. наук, професор, професор кафедры управления производством и инновационной деятельностью предприятий, Николаевский национальный аграрный университет (г. Николаев, Украина)

Факторы динамики инновационных преобразований украинской экономики: суть и особенности влияния

В статье исследуются факторы динамики развития инновационной экономики. Утверждается, что главным фактором, способствующим развитию инновационной экономики Украины, являются внутренние поточные издержки на научно-технические разработки, научные услуги и прикладные исследования, исполненные собственными силами научных организаций. Доказывается, что к перечню срочных мер государственной инновационной политики необходимо отнести усиление борьбы с коррупцией, политическую стабилизацию, усиление роли Антимонопольного комитета Украины и ответственности за нарушение антимонопольного законодательства Украины, повышение уровня защить интеллектуальной собственности и авторского права к международным стандартам, увеличение адресного государственного финансирования научных организаций, производящих инновационные разработки, пользующиеся спросом со стороны реального сектора экономики, разработка государственно-частных пилотных проектов высокотехнологических технопарков на базе ведущих отечественных научных учреждений соответствующего профиля.

Ключевые слова: инновации, издержки на научные разработки, коррупция, политическая нестабильность, инфрляция, интеллектуальная собственность, антимонопольное регулирование, адресное финансирование.

Отримано 28.03.2017 p. 